\title{
XY Sex Reversal and Gonadal Dysgenesis Due to 9p24 Monosomy
}

\author{
Marie T. McDonald, ${ }^{1 *}$ Wendy Flejter, ${ }^{2}$ Susan Sheldon, ${ }^{3}$ Mathew J . Putzi, ${ }^{3}$ and J erome L. Gorski ${ }^{\mathbf{1}}$ \\ ${ }^{1}$ Department of Pediatrics, University of Michigan, Ann Arbor, Michigan \\ ${ }^{2}$ Department of Pediatrics, University of Utah, Salt Lake City, Utah \\ ${ }^{3}$ Department of Pathology, University of Michigan, Ann Arbor, Michigan
}

\begin{abstract}
We describe a case of $X Y$ sex reversal, gonadal dysgenesis, and gonadoblastoma in a patient with a deletion of 9p24 due to a familial translocation. The rearranged chromosome 9 was inherited from the father; the patient's karyotype was $46, X Y, \operatorname{der}(9) t(8 ; 9)$ (p21;p24)pat. A review shows that 6 additional patients with $46, X Y$ sex reversal associated with monosomy of the distal short arm of chromosome 9 have been observed. The observation that all 7 patients with sex reversal share a deletion of the distal short arm of chromosme 9 is consistent with the hypothesis that the region 9p24 contains a gene or genes necessary for male sex determination. This present case narrows the chromosome interval containing a critical sex determination gene to the relatively small region 9p24. A molecular analysis of this region will provide a means to identify a gene invoved in male sex determination. Am. J . Med. Genet. 73:321-326, 1997.

(c) 1997 Wiley-Liss, Inc.
\end{abstract}

KEY WORDS: sex reversal; sex determination; gonadal dysgenesis; 9p monosomy

\section{INTRODUCTION}

The development of male or female gonads and external genitalia is the result of a complex cascade of genetic, cellular, and hormonal interactions. The phe-

Contract grant sponsor: Primary Children's Medical Foundation, Salt Lake City, Utah; Contract grant sponsor: State of Michigan Department of Public Health genetic services; Contract grant number: 38-6006309; Contract grant sponsor: NIH; Contract grant number: K08 HD01154-01.

*Correspondence to: Marie T. McDonald, Department of Pediatrics, 3570 Medical Science Research Building II, Box 0688, University of Michigan Medical Center, Ann Arbor, MI 48109-0688. E-mail: mtmcdon@umich.edu

Received 13 February 1997; Accepted 16 J une 1997 nomenon of $X Y$ sex reversal, the development of a female phenotype in the presence of a male chromosomal constitution, provides an opportunity to study events in the cascade and to further delineate the pathways of mammalian sex determination. A review shows that $X Y$ sex reversal is heterogeneous. I nitially, attention focused on the gene SRY, a Y chromosomal gene which acts as a switch to direct development of a testis from a bipotential gonad and thus sets in motion the development of the male phenotype [Sinclair et al., 1990]. However, deletions or mutations in the SRY gene were found to account for only an estimated $15 \%$ of females with 46,XY sex reversal [Hawkins et al., 1992]. F urther studies uncovered other genes involved in sex determination including the Wilms tumor suppressor locus (WT1) at 11p13 [Pelletier et al., 1991], the steroidogenic factor (SF-1) gene (FTZ-F1) at 9q33 [Shen et al., 1994], the campomelic dysplasia gene (SOX9) at 17q24.3-q25.1 [Wagner et al., 1994], and duplications of sequences within the region Xp21.2-p22.2 (Dosagesensitive sex reversal (DSS)) [Bardoni et al., 1994]. There have al so been reports of $46, X Y$ gonadal dysgenesis in individuals with autosomal structural abnormalities including terminal deletions of $10 q$ [Wilkie et al., 1993] and a duplication of $1 p$ [Wieacker et al., 1996]. Familial forms of 46,XY gonadal dysgenesis with $\mathrm{X}$-linked or autosomal recessive modes of inheritance have also been reported [Simpson et al., 1981; Nazareth et al., 1979]. However, these genes and reported mutations do not account for all cases of $46, X Y$ sex reversal. This observation suggests that more genes, of yet undetermined location and nature, are involved in mammalian sex determination and testicular development.

Here we report a case of $46, X Y$ sex reversal, gonadal dysgenesis, and gonadoblastoma in a child who inherited an unbalanced translocation chromosome resulting in monosomy 9p24. There have been previous reports of sex reversal in association with 9p monosomy [Bennett et al., 1993], and a significantly unbalanced sex ratio with an excess of females has been reported in a published series of patients with deletion $9 p$ [Huret et al., 1988]. Sufficient evidence has thus accumulated to point to the presence of a gene or genes involved in mammalian sex determination on 9p. This case narrows the chromosome interval containing the sex re- 
versal gene to 9p24, a relatively small region. A molecular analysis of this region should provide a means of identifying the regional genes involved in male sex determination.

\section{CLINICAL REPORT}

The proposita, a 10-month-old girl (BB), was referred for evaluation because of a familial chromosome translocation. There was a family history of recurrent miscarriages and karyotype analysis showed a balanced translocation in her father and his twin brother. BB was the first child of healthy parents. Delivery was by Caesarean section at 42 weeks of gestation following a failed induction for postterm pregnancy (Apgar scores 9 at 1 and $5 \mathrm{~min}$, birth weight 4,479 g).

Early motor development was normal. However, on reevaluation at age 3 years, developmental delay was apparent. Testing showed expressive language development at approximately the 18-month level; receptive language development was appropriate for chronological age as were gross and fine motor skills.

On physical examination at 34/12 years, height was $96.5 \mathrm{~cm}$ (50-75th centile), weight $15.4 \mathrm{~kg}$ (50-75th centile), and occipitofrontal circumference (OFC) $52.5 \mathrm{~cm}$ (>95th centile). There were no minor facial anomalies. Cardiovascular and respiratory status was normal. Ex- amination of the abdomen revealed no herniae and no testes were palpable in the inguinal canal. The external genitalia were normal female. The muscul oskel etal system was normal apart from mild metarsus varus and bilateral 5th finger clinodactyly. She had a single right palmar crease. There were no focal neurological abnormalities.

An ECG demonstrated a complete right bundle branch block and an echocardiogram demonstrated a bicuspid aortic valve. Renal ultrasound findings were normal. A pelvic ultrasound study showed the presence of a uterus and vagina; no gonads were identified. FSH and $\mathrm{LH}$ levels were elevated. Because of the risk of gonadal malignancy in dysgenetic intraabdominal gonads [Scully, 1970], bilateral gonadectomy was performed. The presence of a uterus and fallopian tubes was confirmed at laparotomy.

\section{Cytogenetic and Molecular Analyses}

Chromosome analysis showed that the proposita had a $Y$ chromosome and an abnormal unbalanced chromosome constitution with monosomy 9p24 and trisomy 8p21. Her karyotype was 46,XY, der(9)t(8;9)(p21;p24) pat (Fig. 1). A balanced translocation was detected in the paternal uncle when a karyotype was performed as part of the investigation of recurrent miscarriages. The

A

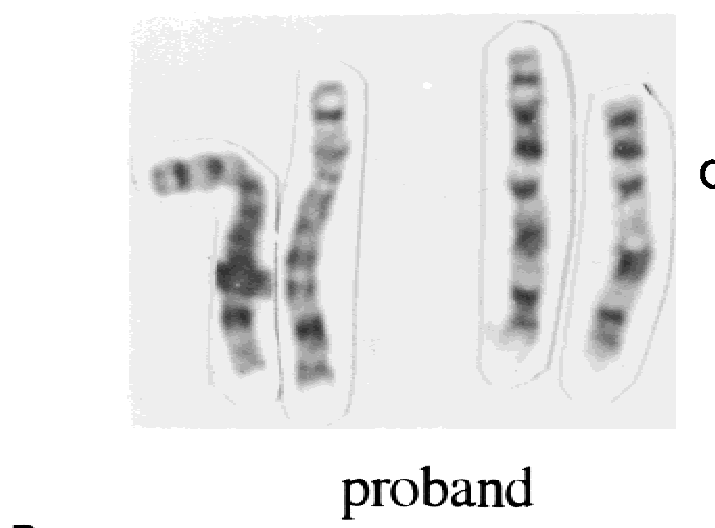

B

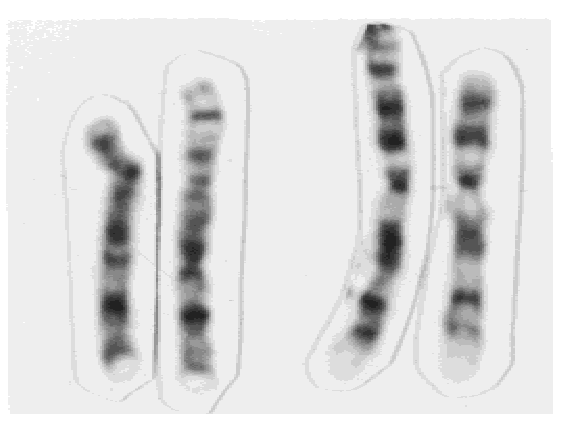

father
C

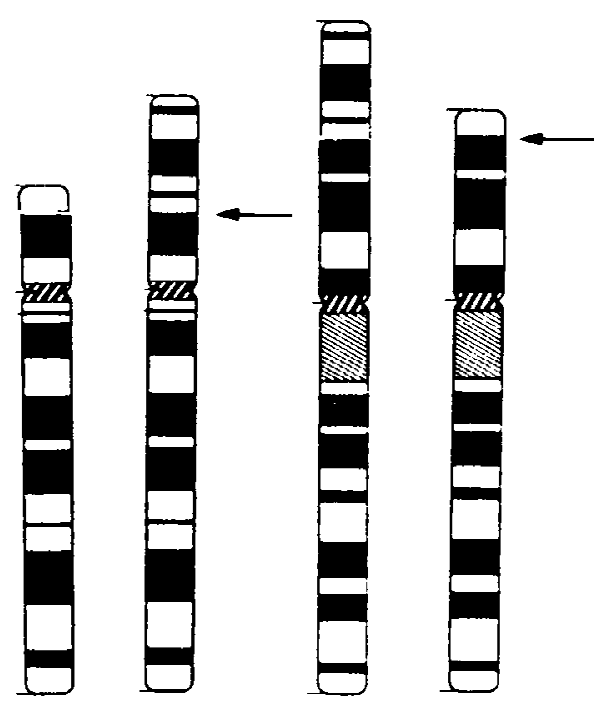

$\operatorname{der}(8) \quad 8 \quad \operatorname{der}(9) \quad 9$

Fig. 1. Partial Giemsa-banded karyotype of normal and rearranged chromosomes 8 and 9 from the proposita and her father. A: Shown from left to right are the patient's normal pair of chromosomes 8, the der(9), and normal 9 chromosomes. B: From left to right, the father's der(8), normal 8, der(9), and normal 9 chromosomes. C: A schematic diagram of chromosomes 8 and 9 with arows showing the breakpoints involved in the translocation. The proposita's karyotype is $46, \mathrm{XY}$, der(9)t(8;9)(p21;p24) and the father's karyotype is $46, \mathrm{XY}, \mathrm{t}(8 ; 9)(\mathrm{p} 21 ; \mathrm{p} 24)$. 
patient's father had the same balanced translocation; his karyotype was 46,XY,t(8;9)(p21;p24) (Fig. 1). Both paternal grandparents had normal karyotypes. Qbanding confirmed that the patient had a Y chromosome with a fluorescence pattern identical to that of her father (data not shown). FISH analysis of metaphase spreads derived from the patient's father with a whole chromosome 9 paint probe (Oncor, MD) showed uniform hybridization along the length of the derivative 9 chromosome except at the tip, and a very small signal on the distal short arm of chromosome 8 (Fig. 2). A similar analysis in the patient showed the presence of the identical rearranged derivative 9 chromosome with deletion of 9p24. However no signal was observed on either chromosome 8 homologs. The identity of the additional material on $9 p$ in the patient and her father was confirmed by fluorescence in situ hybridization (FISH) with a painting probe for chromosome 8 (data not shown). These analyses were consistent with the karyotype analysis and confirmed that the patient was trisomic for 8p21-pter and monosomic for 9p24-pter.

PCR amplification and DNA sequence analysis of SRY revealed no mutations in the highly conserved HMG box binding domain (W. Flejter, in preparation).

\section{Pathology}

Each gonad was ovoid, white, and firm and was appromixately $2.5 \times 0.6 \times 0.8 \mathrm{~cm}$. The outer surfaces were bosselated; the cut surfaces exhibited numerous, aggregated round nodules, 0.1 to $0.2 \mathrm{~cm}$ in diameter, against a background of white, fibrous stroma. No cal- cifications were grossly visible. The patient's 2 gonads exhibited nearly identical histology (Fig. 3). Microscopically the gonads were dysgenetic; no definite ovarian follicles or seminiferous tubules were identified. Each gonad was composed of cellular nests surrounded by a cellular connnective tissue stroma. The nests were generally round and well circumscribed and compressed into thin cords in some areas. Two cell types were discernible within the nests: The first was large and round with clear cytoplasm and a large round nucleus; the second cell type was smaller and variably ovoid or comma-shaped. The cells of this population encircled the larger cells. No mitotic figures were seen in either population. A few scattered, often laminated, microcalcifications were seen within the cell nests throughout the gonads. Although compressed cords were numerous, particularly at the periphery of the gonads, no seminoma was identified. The histol ogic diagnosis was gonadoblastoma.

\section{DISCUSSION}

We report on a case of $46, X Y$ gonadal dysgenesis and sex reversal associated with an unbalanced chromosome constitution with monosomy 9p24-pter and trisomy 8p21-pter. The presence of normal female external genitalia and Müllerian duct derivatives indicates failure of testicular development with a subsequent lack of production of testosterone and Müllerian inhibitory factor (MIF), the two testicular signals required

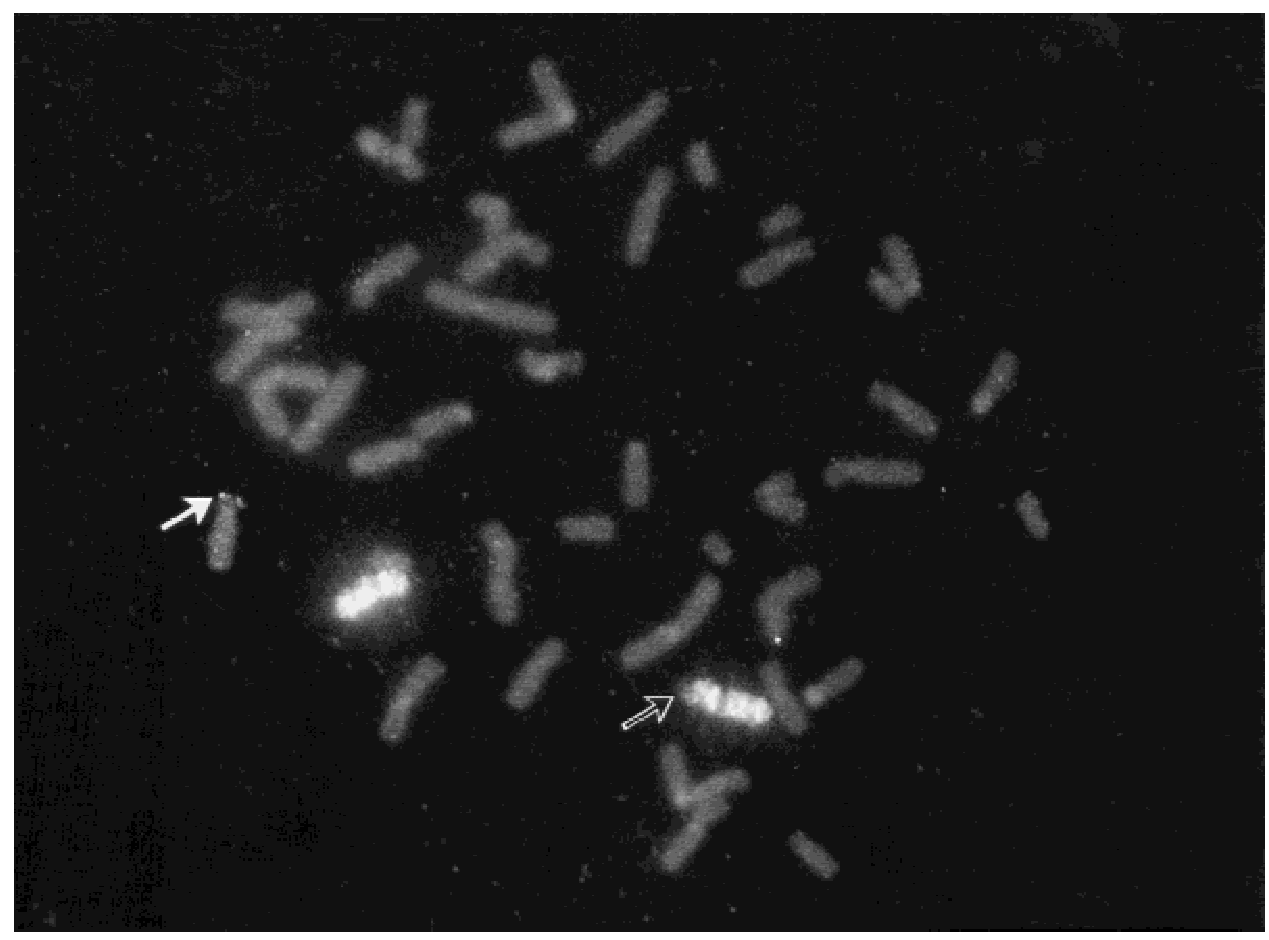

Fig. 2. FISH analysis of the translocated chromosome 9 observed in the proposita's father using a chromosome 9-specific whole chromosome paint probe (Oncor, MD). Hybridization of the chromosome 9 paint probe to metaphase cells from the father showed uniform fluorescent signal al ong the length of one chromosome 9, except at the tip of the distal short arm (open arrow), plus a very small signal on the distal short arm of chromosome 8 (solid white arrow). FISH analysis of metaphase spreads from the daughter with the same probe showed that she had inherited this rearranged chromosome 9 . The lack of signal at the centromeres of each chromosome 9 is due to the absence of alpha satellite sequences in the probe. 


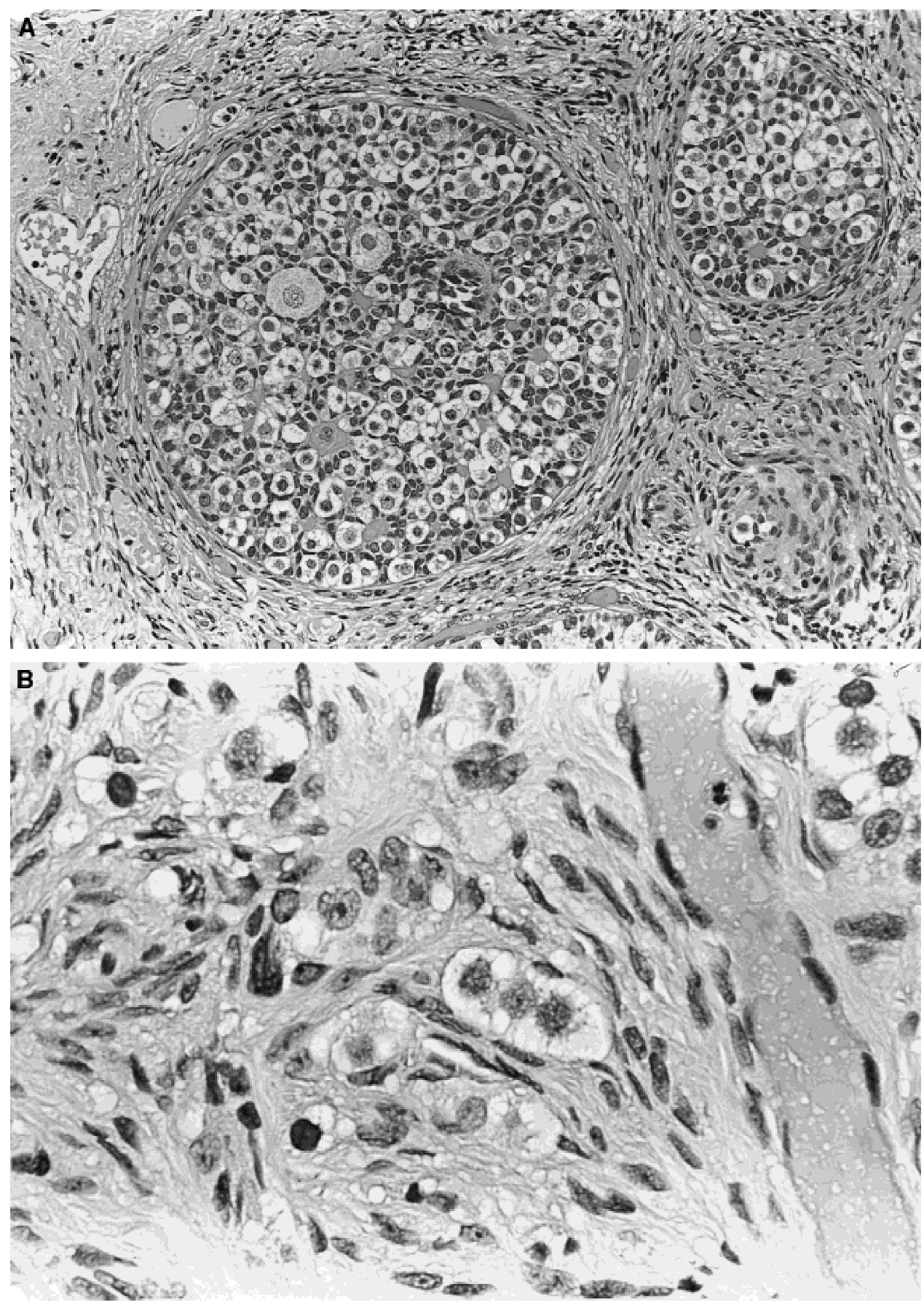

Fig. 3. Histological appearance of the gonads displaying the gonadoblastoma. A: Cellular nests surrounded by a cellular connective tissue stroma. Two cell types are present within the nests: a large, round cell with clear cytoplasm and a smaller variably ovoid or comma-shaped cell. A few microcalcifications are present within the cell nests. B: Some of the cell nests are compressed into cords but no seminoma was observed.

for all subsequent steps in male sex differentiation. Presumably, the ovarian default pathway was followed, but the presence of only one $X$ chromosome in the patient resulted in dysgenetic gonads, devoid of follicles and normal germ cells. Subsequent neoplastic transformation resulted in gonadoblastoma. In addition to providing important insights into the pathway of male sex determination, this case also emphasizes the importance of karyotype analysis in all cases of unexplained devel opmental delay, as the patient's phe- notype, apart from the sex reversal and gonadal dysgenesis with neoplastic transformation, was relatively mild.

There have been 6 previous reports describing 46,XY sex reversal associated with deletions involving 9p (Table I). In 5 cases the deletion of 9p was due to an unbalanced translocation, familial in 4 cases (maternal in 2, paternal in 2). The 6th case was the result of a de novo deletion. The importance of 9p24 in male sexual development is further supported by a review of 80 
TABLE I. Details of Cases With Depletion 9p and Sex Reversal

\begin{tabular}{|c|c|c|c|}
\hline Karyotype & $\begin{array}{l}\text { Deleted } \\
\text { segment }\end{array}$ & Genital phenotype & Reference \\
\hline $46, X Y, \operatorname{der}(9), t(9 ; 13)(9 p 21 ; q 21) m a t$ & 9p21-pter & $\begin{array}{l}\text { Ambiguous external genitalia: clitoromegaly, } \\
\text { inguinal testes, normal vagina, bifid uterus, } \\
\text { immature testicular tissue }\end{array}$ & $\begin{array}{l}\text { J otterand and J uillard } \\
\text { [1976] }\end{array}$ \\
\hline 46,XY, der (9),t(3;9)(p21.33;p22.1)mat & 9p22.1-pter & $\begin{array}{l}\text { Hypoplastic labia minora and clitoris, normal } \\
\text { vagina, primary amenorrhea }\end{array}$ & Fryns et al. [1986] \\
\hline $46, X Y, \operatorname{der}(9), t(7 ; 9)(q 31.1 ; p 23)$ pat & 9p23-pter & $\begin{array}{l}\text { Female external genitalia, vestigial uterus and } \\
\text { oviducts, small testes with no germ cells, } \\
\text { wolffian duct remnants }\end{array}$ & Crocker et al. [1988] \\
\hline $46, X Y, \operatorname{der}(9), t(2 ; 9)(p 21 ; p 24)$ & 9p24-pter & Female external genitalia, uterus present & Hoo et al. [1989] \\
\hline $46, \mathrm{XY}, \operatorname{der}(9), \mathrm{t}(4 ; 9)(? ; \mathrm{p} 24)$ pat & 9p24-pter & Female external genitalia & Magenis et al. [1990] \\
\hline $46, X Y, \operatorname{del}(9)(p 23)$ & 9p23-pter & $\begin{array}{l}\text { Female external genitalia, normal vagina, } \\
\text { uterus, fallopian tubes, streak gonads }\end{array}$ & Bennett et al. [1993] \\
\hline $46, X Y, \operatorname{der}(9) t(8 ; 9)(p 21 ; p 24)$ pat & 9p24-pter & $\begin{array}{l}\text { Female external genitalia, normal vagina and } \\
\text { uterus, streak gonads, bilateral } \\
\text { gonadoblastoma }\end{array}$ & Present case \\
\hline
\end{tabular}

published cases of deletions of the short arm of chromosome 9; among these cases there was a significantly unbalanced sex ratio with an excess of females [Huret et al., 1988]. In addition, 25 of 60 informative cases had abnormalities of the external genitalia [Huret et al., 1988]. The case described here confirms the presence of a gene or genes in the region 9p24 which is necessary for male sex determination. Region 9p24-pter defines the minimum deleted segment common to all 6 previous cases; this observation defines a critical region on distal $9 p$ that contains a gene responsible for sex reversal.

Therefore, monosomy of distal 9p material is the most likely cause of the sex reversal in this and the other $9 p$ deletion sex reversal cases. Other explanations are less tenable. It is unlikely that the chromosome transl ocation breakpoints in this case disrupted a gene important in sex determination as the father was a balanced translocation carrier and a normal fertile male. The cytogenetically observed distances between the breakpoints on $9 p$ in these 7 cases also makes it less likely that these chromosome 9 breakpoints disrupt a single genetic locus. It is also unlikely that the trisomy 8p21 plays a role in the sex reversal. Abnormal sex determination has not been a consistent finding in other trisomy 8p cases [Memo et al., 1988]. In addition, the trisomic segment is different in each of the other 5 $46, X Y$ sex reversal cases associated with an unbalanced translocation involving $9 p$ and in the sixth case of $46, X Y$ sex reversal the monosomy $9 p$ was the result of a de novo deletion. The observation that the deleted chromosome 9 was inherited from the mother in 2 cases and the father in 3 cases makes an imprinting effect unlikely.

The mechanism whereby monosomy 9p24 causes failure of normal testicular development and subsequent sex reversal remains to be determined. One possible explanation is that deletion of 9p24 uncovers a heterozygous mutation. A mutation may be present in an autosomal recessive gene on the nonrearranged chromosome 9 and loss of the normal allele on the deleted chromosome 9 might result in expression of the mutant sex reversal phenotype. At least 3 autosomal recessive sex reversal loci in mouse have been identified to date [Eicher et al., 1996]; however the homolo- gous human chromosomal regions do not appear to include band 9p24.

A more likely explanation is that haploinsufficiency of a gene on 9p24 may interrupt normal testis development. Such a mechanism has been suggested for SOX9 in campomelic dysplasia, a dominant, haploinsufficiency disorder in which dosage of SOX9 is of critical importance. Reduced dosage of the SOX9 protein results in gonadal dysgenesis and sex reversal [Wagner et al., 1994]. T-associated sex reversal (Tas), a locus on chromosome 17 of the mouse, is an autosomal gene necessary for normal testis development. When present in the hemizygous condition with a Y chromosome of $A K R / J$ origin, there is failure of testis development and $X Y$ mice develop as females or hermaphrodites [Washburn and Eicher, 1989]. This may indicate that the hemizygous condition is inadequate to support normal testis development. Thus, this may be another example of the importance of gene dosage in sex determination [Washburn and Eicher, 1989]. DSS [Bardoni et al., 1994] also appears to exert its effect on mammalian sex determination through altered dosage. When duplicated, this locus causes male sex reversal. This phenomenon may reflect past function of these genes in an ancestral dose-dependent sex-determination mechanism.

At the molecular level the process that determines the fate of the bipotential gonad is largely unexplored both upstream and downstream of SRY. Analysis of these cases of sex reversal in association with chromosome 9p24 abnormal ities may provide a means to identify and study other genes involved in the process. Identification of the gene or genes involved on 9p24 may provide insight into the mechanisms whereby deletion of distal 9p causes sex reversal, and may provide further insight into the pathway of sex determination.

\section{ACKNOWLEDGMENTS}

We thank the family for their cooperation in publishing this report. This work was supported, in part by, Primary Children's Medical Foundation, Salt Lake City, UT (WF), State of Michigan Department of Public Health genetic services grant 38-6006309 (J LG), and NIH grant K08 HD01154-01 (MM). 


\section{REFERENCES}

Bardoni B, Zanaria E, Guioli S, Floridia G, Worley KC, Tonini G, Ferrante E, Chiumello G, McCabe ER, Fraccaro M, Zuffardi O, Camerion G (1994): A dosage sensitive locus at chromosome Xp21 is involved in male to female sex reversal. Nat Genet 7:497-501.

Bennett CP, Docherty Z, Robb SA, Ramani P, Hawkins J R, Grant D (1993): Deletion 9p and sex reversal. J Med Genet 30:518-520.

Crocker M, Coghill SB, Cortinho R (1988): An unbalanced autosomal translocation (7;9) associated with feminization. Clin Genet 34:70-73.

Eicher EM, Washburn LL, Schork NJ, Lee BK, Shown EP, Xu X, Dredge RD, Pringle MJ, Page DC (1996): Sex-determining genes on mouse autosomes identified by linkage analysis of C57BL/6] $-Y^{\mathrm{POS}}$ sex reversal. Nat Genet 14:206-209.

Fryns J P, Kleczkowska A, Casaer P, van den Berghe H (1986): Double autosomal chromosomal aberration ( $3 p$ trisomy/9p monosomy) and sexreversal. Ann Gnt 29:49-52.

Hawkins J R, Taylor A, Berta P, Levilliers J , Van der AB, Goodfellow PN (1992): Mutational analysis of SRY: Nonsense and missense mutations in XY sex reversal. Hum Genet 88:471-474.

Hoo J J, Salafsky IS, Lin CC (1989): Possible localisation of a recessive testis forming gene on 9p24. Am J Hum Genet (Suppl) 45:A78.

Huret J L, Leonard C, Forestier B, Rethor MO, Lejeune J (1988): Eleven new cases of del (9p) and features from 80 cases. J Med Genet 25:741749.

J otterand M, J uillard E (1976): A new case of trisomy for the distal part of $13 q$ due to maternal translocation, $t(9 ; 13)(p 21 ; q 21)$. Hum Genet 33 213-222.

Magenis RE, Allen LJ, Brown MG, Dougherty TM, Black M, HafitsBorchardt V, Toth-Fejel S, Lawce H, Smith L (1990): 9p monosomy associated with $\mathrm{XY}$ gonadal dysgenesis: A contiguous gene syndrome? Am J Hum Genet (Suppl) 47:A33.

Memo L, Lenzini E, Baccichetti C (1988): Trisomy 8p by malsegregation of a $t(5 ; 8)(p 15 ; p 11)$ mat in a case of $X Y$ pure gonadal dysgenesis. Ann Genet 31:181-185.
Nazareth HR, Moreira-Filho CA, Cunha AJ , Vieira-FilhoJ P, Lengyel AM, Lima MC (1979): H-Y antigen in 46, XY pure testicular dysgenesis. Am J Med Genet 3:149-154.

Pelletier J , Bruening W, Kashtan CE, Mauer SM, Manivel J C, Striegel J E, Houghton DC, J unien C, Habib R, Fouser L, Fine RN, Silverman BL, Haber DA, Housman D (1991): Germline mutations in the Wilms' tumor suppressor gene are associated with abnormal urogenital development in Denys-Drash syndrome. Cell 67:437-447.

Scully RE (1970): Gonadoblastoma. A review of 74 cases. Cancer 25:13401356.

Shen WH, Moore C, I keda Y, Parker K, Ingraham H (1994): Nuclear re ceptor steroidogenic factor 1 regulates the Müllerian inhibiting substance gene: A link to the sex determination cascade. Cell 77:651-661.

Simpson J L, Blagowidow N, Martin AO (1981): XY gonadal dysgenesis: Genetic heterogeneity based upon clinical observations, $\mathrm{H}-\mathrm{Y}$ antigen status and segregation analysis. Hum Genet 58:91-97.

Sinclair AH, Berta P, Palmer MS, Hawkins J R, Griffiths BL, Smith MJ , Foster J W, Frischauf AM, Lovell-Badge R, Goodfellow PN (1990): A gene from the human sex-determining region encodes a protein with homology to a conserved DNA-binding motif. Nature 346:240-244.

Wagner T, Wirth J, Meyer J, Zabel B, Held M, Zimmer J, Pasantes J, Bricarelli FD, Keutel J , Hustert E, Wolf U, Tommerup N, Schempp W, Scherer G (1994): Autosomal sex reversal and campomelic dysplasia are caused by mutations in and around the SRY-related gene SOX9. Cell 79:1111-1120

Washburn LL, Eicher EM (1989): Normal testis determination in the mouse depends on genetic interaction of a locus on chromosome 17 and the $Y$ chromosome. Genetics 123:173-179.

Wieacker P, Missbach D, J akubiczka S, Borgmann S, Albers N (1996): Sex reversal in a child with the karyotype 46,XY, dup (1)(p22.3p32.3). Clin Genet 49:271-273.

Wilkie AO, Campbell FM, Daubeney P, Grant DB, Daniels RJ, Mullarkey M, Affara NA, Fitchett M, Huson SM (1993): Complete and partial XY sex reversal associated with terminal deletion of 10q: Report of 2 cases and literature review. Am J Med Genet 46:597-600. 